\title{
Transgenic Sugarcane Resistant to Sorghum mosaic virus Based on Coat Protein Gene Silencing by RNA Interference
}

\author{
Jinlong Guo,, 1,2 Shiwu Gao,, Qinliang Lin, 1,2 Hengbo Wang, ${ }^{1,2}$ \\ Youxiong Que, ${ }^{1,2}$ and Liping $\mathrm{Xu}^{1,2}$ \\ ${ }^{1}$ Key Laboratory of Sugarcane Biology and Genetic Breeding, Ministry of Agriculture, Fujian Agriculture and Forestry University, \\ Fuzhou 350002, China \\ ${ }^{2}$ National Research and Development Center for Sugarcane Industry Technology, Fujian Agriculture and Forestry University, \\ Fuzhou 350002, China
}

Correspondence should be addressed to Youxiong Que; queyouxiong@hotmail.com and Liping Xu; xlpmail@126.com

Received 25 June 2014; Revised 30 July 2014; Accepted 21 August 2014

Academic Editor: Calvin Yu-Chian Chen

Copyright (C) 2015 Jinlong Guo et al. This is an open access article distributed under the Creative Commons Attribution License, which permits unrestricted use, distribution, and reproduction in any medium, provided the original work is properly cited.

\begin{abstract}
As one of the critical diseases of sugarcane, sugarcane mosaic disease can lead to serious decline in stalk yield and sucrose content. It is mainly caused by Potyvirus sugarcane mosaic virus (SCMV) and/or Sorghum mosaic virus (SrMV), with additional differences in viral strains. RNA interference (RNAi) is a novel strategy for producing viral resistant plants. In this study, based on multiple sequence alignment conducted on genomic sequences of different strains and isolates of SrMV, the conserved region of coat protein (CP) genes was selected as the target gene and the interference sequence with size of $423 \mathrm{bp}$ in length was obtained through PCR amplification. The RNAi vector pGII00-HACP with an expression cassette containing both hairpin interference sequence and cp4-epsps herbicide-tolerant gene was transferred to sugarcane cultivar ROC22 via Agrobacterium-mediated transformation. After herbicide screening, PCR molecular identification, and artificial inoculation challenge, anti-SrMV positive transgenic lines were successfully obtained. SrMV resistance rate of the transgenic lines with the interference sequence was $87.5 \%$ based on SrMV challenge by artificial inoculation. The genetically modified SrMV-resistant lines of cultivar ROC22 provide resistant germplasm for breeding lines and can also serve as resistant lines having the same genetic background for study of resistance mechanisms.
\end{abstract}

\section{Introduction}

Sugarcane (Saccharum spp. L.), a major sucrose accumulator and biomass producer, is one of the most important field crops grown in the tropics and subtropics [1]. It accounts for $92 \%$ of all sugar produced in China [2] and $80 \%$ of that in the world. Sugarcane mosaic disease is one of the most serious sugarcane diseases. It primarily damages chloroplasts, blocks photosynthesis, and decreases photosynthetic products, thus resulting in a decline in yield and sugar content [2]. Sugarcane mosaic disease is caused by the sugarcane mosaic virus subgroup of Potyvirus sugarcane mosaic virus (SCMV) and/or Sorghum mosaic virus (SrMV) [3]. Potyvirus is a singlestranded RNA virus, with simple genome structure encoding 10 mature proteins, named from $\mathrm{N}$-terminal to C-terminal: the first protein (P1), helper component proteinase (HC-pro), the third protein (P3), the first $6 \mathrm{~K}$ protein $(6 \mathrm{~K} 1)$, cylindrical inclusion protein $(\mathrm{CI})$, the second $6 \mathrm{~K}$ protein $(6 \mathrm{~K} 2)$, viral protein genome-linked (VPg), nuclear inclusion a protein (NIa), nuclear inclusion $\mathrm{b}$ protein $(\mathrm{NIb})$, and coat protein (CP) [4].

The virus strain differentiation is complex, with both of the virus members that cause sugarcane mosaic disease having several different virus strains [5]. At least eight stains have been reported [6], including five from SCMV and three from SrMV. The mixed infection of different virus strains also occurs $[3,6,7]$, and dominant virus strains are variable [8]. In the 1980s there were at least three strains of SCMV including strains $A, D$, and $E$ in mainland China [9]. However, the dominant pathogen has become strain $\mathrm{H}$ of SrMV in the last ten years [10]. The simplicity of pathogenic virus genome quickens the change of dominant strains. Coupled with 
the complexity of the genetic background of sugarcane, the difficulty in the crossbreeding of virus-resistant varieties is obvious, especially for breeding sugarcane varieties resistant to multiple virus strains.

Improving plant antiviral resistance by gene silencing has proven to be effective in several plant-virus biosystems. Abel et al. first transferred CP genes of tobacco mosaic virus (TMV) into tobacco and successfully obtained anti-TMV tobacco plants [11]. Subsequently, different genes in Potyvirus genome were introduced into various plants to obtain corresponding resistant plants [12]. Joyce et al. introduced the $\mathrm{CP}$ gene of SCMV into sugarcane, and the CP-transformed plants displayed various phenotypes after SCMV challenge [13]. Ingelbrecht et al. introduced the $\mathrm{CP}$ gene of SrMV-H strain into sugarcane and obtained a range of different resistance types [14]. Yao et al. transferred the CP gene of SCMVE strains into S. officinarum Badila and obtained SCMVresistant transgenic lines but, after field experiments, found that some of them showed symptoms of mosaic disease, which were shown to be infected with SrMV-H and SCMV by RT-PCR [15]. Therefore, resistance performance of transgenic offspring obtained by the introduction of complete $\mathrm{CP}$ genes is complex, and resistance loss to the same or different virus strains in transgenic plants suggests that an improved method is necessary.

Gene silencing through RNA interference (RNAi) appears to be present in most eukaryotic organisms. Homologous RNA is degraded with the introduction of double-stranded RNA (dsRNA), which can lead to target gene silencing [16]. The target gene to be silenced can include a single gene or part sequence of a single gene that is targeted for suppression or can include multiple consecutive segments of a target gene, multiple nonconsecutive segments of a target gene, multiple alleles of a target gene, or multiple target genes from one or more species. RNAi-based antiviral breeding appears to be a promising strategy for development of virus resistance transgenic plants. There have been many successful examples of RNAi-mediated virus resistance improvement in crops, such as soybean [17], tobacco $[18,19]$, potato [20], barley [21], tomato [22], maize [23], and rice [24]. In sugarcane, the application of RNAi technology to suppress lignin biosynthesis was reported $[25,26]$, but no study on the application of RNAi technology in improving disease resistance has been reported. SrMV, the pathogen of sugarcane mosaic disease, is a single-stranded RNA virus, which replicates using a viral RNA polymerase. Viral genes in the form of dsRNA generate during replication, which is the basis of using RNAi technology for its control.

In this study, we have used RNAi technology, taking highly conserved sequences of SrMV CP gene as a silencing target, and RNAi expression vector with hairpin structures and introduced them into sugarcane via Agrobacteriummediated transformation. We then performed screening and biological identification to obtain anti-Sorghum mosaic virus transgenic sugarcane plants. This study provides sugarcane transgenic lines with different resistances in the same genetic background for study of resistance mechanisms and for breeding of multiresistance to various SrMV strains.

\section{Materials and Methods}

2.1. Bacterial Strains and Plasmids. Escherichia coli strain DH5A, Agrobacterium tumefaciens strain EHA105, and intermediate vector $\mathrm{pHANNIBAL}$ were provided by the Key Laboratory of Sugarcane Biology and Genetic Breeding, Ministry of Agriculture (Fuzhou, China). The glyphosate tolerance gene $c p 4$-epsps was obtained from roundup ready soybean by PCR and verified by sequencing, and the intermediate vector pGIIHA containing 35S promoter-cp4-epsps-CaMV polyA cassette was constructed subsequently in previous study.

2.2. Reagents and Plant Materials. Reverse transcriptase (AMV), restriction endonucleases, T4 DNA ligase, and PCR kits were purchased from Fermentas (USA); dephosphorylation (BAP) kit was purchased from Takara (Dalian, China); Wizard DNA clean-up kit gel extraction kit was purchased from Promega Corporation (USA); plant genomic DNA extraction kit was purchased from TIANGEN (Beijing, China); components in MS medium were purchased from Sangon (Shanghai, China); Trizol reagents were purchased from Invitrogen (USA); Timentin disodium salt and 2,4dichlorophenoxyacetic acid (2-4-D) were purchased from Sigma (USA); and herbicide (47\% isopropylamine salt of $\mathrm{N}$ glycine) applicable by foliar spraying was purchased from Sannong Co., Ltd. (Fujian, China). ROC22 was the most popular cultivar in China, which was provided by the Key Laboratory of Sugarcane Biology and Genetic Breeding, Ministry of Agriculture (Fuzhou, China).

2.3. Medium. Infection medium $\mathrm{M} 1$ is $1 / 2 \mathrm{MS}+100 \mu \mathrm{mol} / \mathrm{L}$ acetosyringone $+20 \mathrm{~g} / \mathrm{L}$ sucrose, $\mathrm{pH}$ 5.8; cocultivation medium M2 is $1 / 2 \mathrm{MS}+3.0 \mathrm{mg} / \mathrm{L} 2.4-\mathrm{D}+100 \mu \mathrm{mol} / \mathrm{L}$ acetosyringone $+20 \mathrm{~g} / \mathrm{L}$ sucrose $+5 \mathrm{~g} / \mathrm{L}$ agar powder, $\mathrm{pH} 5.8$; subculture medium M3 is MS + 3.0 mg/L 2.4-D + $300 \mathrm{mg} / \mathrm{L}$ Timentin $+8.0 \mathrm{mg} / \mathrm{L}$ herbicide $+30 \mathrm{~g} / \mathrm{L}$ sucrose $+6 \mathrm{~g} / \mathrm{L}$ agar powder, pH 5.8; differential medium M4 is $\mathrm{MS}+2.0 \mathrm{mg} / \mathrm{L}$ $\mathrm{BA}+0.5 \mathrm{mg} / \mathrm{L} \mathrm{KT}+0.2 \mathrm{mg} / \mathrm{L} \mathrm{NAA}+300 \mathrm{mg} / \mathrm{L}$ Timentin + $6.0 \mathrm{mg} / \mathrm{L}$ herbicide $+30 \mathrm{~g} / \mathrm{L}$ sucrose $+6 \mathrm{~g} / \mathrm{L}$ agar powder, $\mathrm{pH}$ 5.8; rooting medium $\mathrm{M} 5$ is $1 / 2 \mathrm{MS}+0.2 \mathrm{mg} / \mathrm{L} 6-\mathrm{BA}+3 \mathrm{mg} / \mathrm{L}$ $\mathrm{NAA}+60 \mathrm{~g} / \mathrm{L}$ sucrose $+6 \mathrm{~g} / \mathrm{L}$ agar powder, $\mathrm{pH} 5.8$.

2.4. RNAi Target Sequence Selection. Genome sequences of the SrMV strains ( $\mathrm{H}, \mathrm{I}$, and $\mathrm{M}$ ) isolated from sugarcane were collected from GenBank. Using DNAMAN 5.22 software (http://www.lynnon.com/), multiple sequence alignment was performed to determine the most conservative nucleic acid segment as RNAi target sequence. The fast alignment was generated using DNAMAN 5.22 with default parameters (Gap penalty was set at 7, K-tuple at 3, and number of Top at 5). The accession numbers of the chosen sequences in alignment were EU189035, EU189036, EU189037, EU189041, EU189042, EU189038, EU189043, EU189044, EU189045, EU189046, EU189039, EU189040, U07219, AJ310198, NC004035, and SMU57358 and SrMV FZ strain was kept in our lab (a SrMV strain isolated from Fuzhou, China, unsubmitted). 
2.5. Interference Fragment Preparation and Hairpin Intermediate Vector Construction. According to multiple sequence alignment results, a pair of specific primers targeting the most conservative segment were designed, with extra Xba I and Xho I endonuclease restriction sites on the $5^{\prime}$ end of the forward primer CPS and Cla I and Kpn I on the $5^{\prime}$ end of the forward primer CPA. The primer sequences are as follows:

CPS:

CPA:

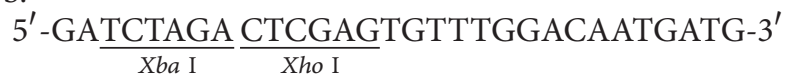

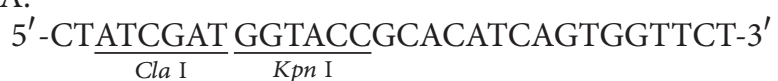

Target sequence for RNAi was amplified by PCR using SrMV FZ as template. The $50 \mu \mathrm{L}$ PCR reaction mix contained $5.0 \mu \mathrm{L} 10 \times$ PCR buffer, $4.0 \mu \mathrm{L}$ deoxynucleotide triphosphates (dNTPs) $(2.5 \mathrm{mM}), 2.0 \mu \mathrm{L}$ each of forward and reverse primers $(10 \mu \mathrm{M}), 2.0 \mu \mathrm{L}$ template $(100 \mathrm{ng})$, and $0.25 \mu \mathrm{L} \mathrm{Ex}-$ Taq enzyme $(5 \mathrm{U} / \mu \mathrm{L})$. The $\mathrm{ddH}_{2} \mathrm{O}$ was added as supplement. The PCR amplification program consisted of predenaturation for $5 \mathrm{~min}$ at $94^{\circ} \mathrm{C}$, denaturation for $30 \mathrm{~s}$ at $94^{\circ} \mathrm{C}$, annealing for $30 \mathrm{~s}$ at $60^{\circ} \mathrm{C}$, and extension for $30 \mathrm{~s}$ at $72^{\circ} \mathrm{C}$ for 30 cycles; final extension was for $10 \mathrm{~min}$ at $72^{\circ} \mathrm{C}$. The PCR product was purified by gel extraction kit to prepare for digestion. The PCR product was separated in $2 \%$ agarose gel. The target DNA fragments were excised and purified using an agarose gel purification kit. Using the two sets of restriction enzymes, Cla I/Xba I and Xho I/Kpn I, successively, the target sequence was inserted into the two sides of the intronic region of pHANNIABL vector. A clone with a recombinant plasmid was validated by PCR, double digestion, and sequencing and was termed as PHANNIABL-CP.

2.6. Construction of the RNAi Expression Vector. The pGIIHA intermediate vector was digested with Not I and then purified by gel extraction kit. The purified products were dephosphorylated according to manual of the dephosphorylation (BAP) kit. Not I-digested hairpin interference cassette fragments from pHANNIBAL-CP were inserted into the Not I site of pGIIHA. A clone with a recombinant plasmid was validated by PCR, double digestion, and sequencing and was termed as pGII00-HACP.

2.7. Preparation of the Engineering Bacteria. According to the freeze-thaw method reported by Holsters et al. [27], the RNAi vector pGII00-HACP was transformed into $A$. tumefaciens EHA105. The positive clone identified by PCR was inoculated into the $\mathrm{LB}$ medium containing kanamycin $\left(50 \mu \mathrm{g} \cdot \mathrm{mL}^{-1}\right)$ and rifampicin $\left(35 \mu \mathrm{g} \cdot \mathrm{mL}^{-1}\right)$ for shake culture at $150 \mathrm{rpm}$ at $37^{\circ} \mathrm{C}$. When $\mathrm{OD}_{600}$ reached 1.0 to 1.2 , the culture was centrifuged at $5,000 \mathrm{rpm}$ for $5 \mathrm{~min}$ at room temperature to discard the supernatant. The pellet was collected and resuspended with M1 medium and then centrifuged at 5,000 rpm for $5 \mathrm{~min}$ at room temperature again to discard the supernatant. The pellet thus obtained was resuspended and diluted with $\mathrm{M} 1$ medium to $\mathrm{OD}_{600}=1.0$.

2.8. Agrobacterium-Mediated Transformation and Screening. Leaf explants from sugarcane ROC22 were cultured on MS medium supplemented with $3.0 \mathrm{mg} / \mathrm{L}$ 2,4-D for one week and then cocultivated with recombinant $A$. tumefaciens EHA105 for $30 \mathrm{~min}$. The plant tissue was picked out and sucked dry with filter paper and cultured on M2 medium for 2-3 d; then the plant tissue was transferred to M3 culture medium and screened for 2-3 generations. After that, the plant tissue was transferred to M4 differential medium, followed by a period of culture on M5 rooting medium when the tissue culture seedlings grew to $4 \sim 5 \mathrm{~cm}$ in length. The seedlings were then transferred to 72 -well nutrition plate when their roots reached about $2.5 \mathrm{~cm}$. After the seedlings were transplanted, the plants were sprayed with liquid herbicide solutions at the concentrations of $3.0 \%$ and survivors from the herbicide treatments were selected.

2.9. PCR for Positive Identification. Genome DNA extracted from herbicide-resistant and control plants was diluted to a concentration of $50 \mathrm{ng} / \mu \mathrm{L}$ and was used as PCR template. 35S promoter and cp4-epsps gene were selected as the target genes for identification. Genome DNA of the herbicide-resistant plants was isolated and tested by PCR, using pGII00-HACP as a positive control, genome DNA of untransformed plants as a negative control, and $\mathrm{ddH}_{2} \mathrm{O}$ as a blank control.

The primer sequences for the $35 \mathrm{~S}$ promoter were $35 \mathrm{SPro}$ F: $5^{\prime}$-TCTAACAGAACTCGCCGTGAA- $3^{\prime}$ and 35Spro R: $5^{\prime}$-AAGGGTCTTGCGAAGGATAGT- ${ }^{\prime}$, and the primers sequences for the cp4-epsps gene were cp4-epsps F: $5^{\prime}$ GTCCTTCATGTTCGGCGGTCTC- $3^{\prime}$ and cp4-epsps R: $5^{\prime}$-ACGTCGATGACTTGGCTGGTGA- $3^{\prime}$. The $50 \mu \mathrm{L}$ PCR reaction mix contained $5.0 \mu \mathrm{L} 10 \times$ PCR buffer; $4.0 \mu \mathrm{L}$ deoxynucleotide triphosphates (dNTPs) $(2.5 \mathrm{mM}) ; 2.0 \mu \mathrm{L}$ each of forward and reverse primers $(10 \mu \mathrm{M}) ; 2.0 \mu \mathrm{L}$ plasmid DNA (100 ng); and $0.25 \mu \mathrm{L}$ Ex-Taq enzyme $(5 \mathrm{U} / \mu \mathrm{L})$. The sterile $\mathrm{ddH}_{2} \mathrm{O}$ was added as supplement. The PCR amplification program consisted of predenaturation for $5 \mathrm{~min}$ at $94^{\circ} \mathrm{C}$, denaturation for $30 \mathrm{~s}$ at $94^{\circ} \mathrm{C}$, annealing for $30 \mathrm{~s}$ at $57^{\circ} \mathrm{C}$, and extension for $30 \mathrm{~s}$ at $72^{\circ} \mathrm{C}$ for 30 cycles, and final extension was for $10 \mathrm{~min}$ at $72^{\circ} \mathrm{C}$. The PCR products were separated by $2.0 \%$ agarose gel electrophoresis, and the results were analyzed by gel imaging and analysis system.

2.10. Identification of SrMV Resistance by Artificial Inoculation. According to Gómez et al. [28], sugarcane leaves with typical mosaic symptoms were collected and diagnosed with SrMV infection. The artificial inoculation method according to Użarowska et al. [29] used the SrMV-positive leaf samples as the virus infection source.

\section{Results and Analysis}

3.1. RNAi Target Sequence Selection. Thirteen sequences of the SrMV CP gene and four sequences of the SrMV whole genome in NCBI were selected for multiple sequence alignment analysis. Figure 1 showed that CP genes with $87.39 \%$ homology were the most conservative fragment in SrMV genome sequence. Therefore, a conserved region of $423 \mathrm{bp}$, from $573 \mathrm{bp}$ to $995 \mathrm{bp}$ in $\mathrm{CP}$ genes, was identified as the interference fragment sequence. 


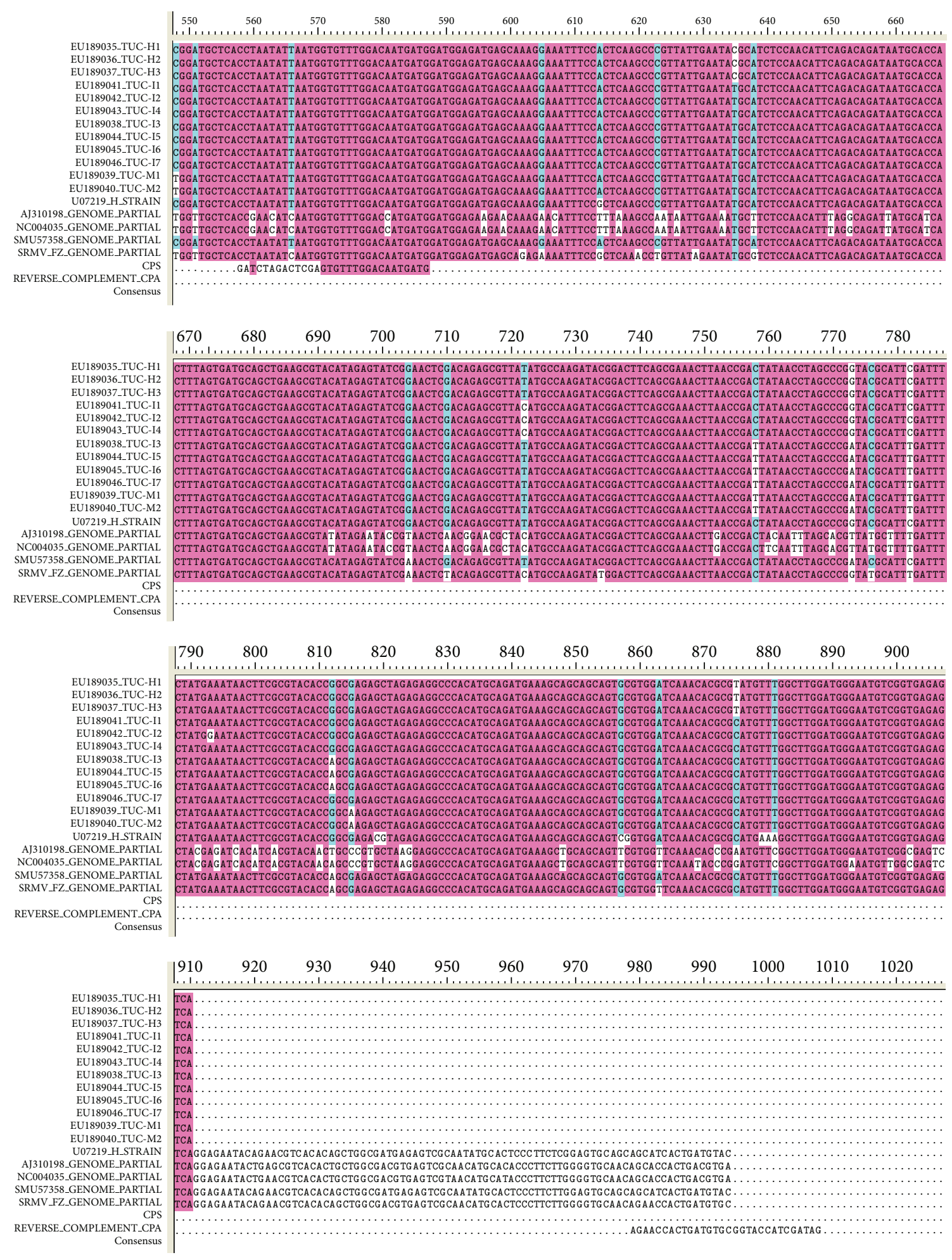

FIGURE 1: Multiple sequence alignment of SrMV CP genes. 


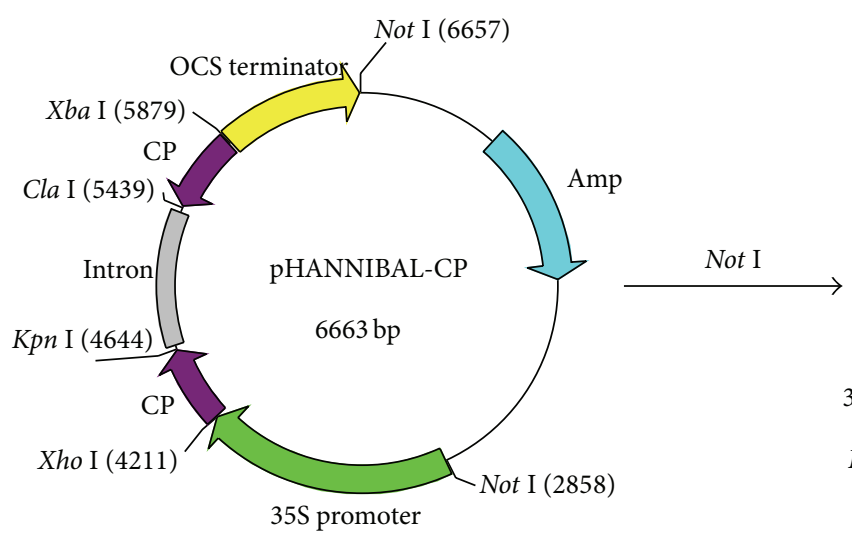

(a)

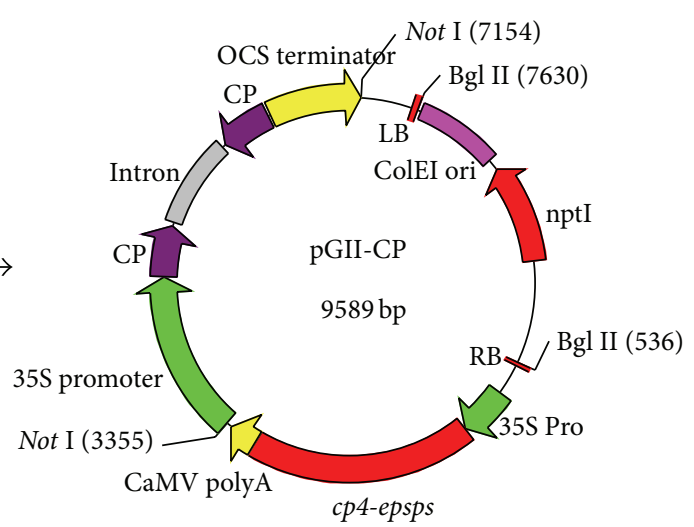

(b)

FIGURE 2: A simplified flowchart showing the construction of binary vectors. (a) Vector diagram of pHANNIBAL-CP; (b) diagram of RNAi expression vector pGII00-HACP.

3.2. Interference Fragment Preparation and Hairpin Intermediate Vector Construction. The target interference fragment with the expected length of $423 \mathrm{bp}$ was obtained by PCR and verified by sequencing. Using the two sets of restriction endonuclease-Kpn I/Xho I or Xba I/Cla I, the $423 \mathrm{bp}$ of partial CP gene and its reverse compliment fragment were successively inserted into each intron site contained in pHANNIBAL and enabled the hairpin intermediate vector pHANNIBAL-CP to make a hairpin loop (Figure 2(a)).

3.3. Construction of RNAi Expression Vector. Recombinant RNAi expression vector was identified by Not I restriction analysis, PCR, and sequencing (data not shown), and the positive hairpin RNAi expression vector was termed as pGII00-HACP (Figure 2(b)).

3.4. Agrobacterium-Mediated Transformation and Screening. The constructed RNAi expression vector pGII00-HACP was transformed into A. tumefaciens EHA105 and used to infect sugarcane calli. After coculture, selective subculture and differentiation culture under herbicide stress, and rooting culture (Figure 3), about five hundred regenerated seedlings were obtained.

3.5. Herbicide Resistance Screening and PCR Detection of Resistant Regenerated Plants. A portion of the regenerated putative recombinants survived herbicide treatment (Figure 4). Among these, 16 plants from 50 survivors were further identified as positive by PCR, exhibiting existence of $463 \mathrm{bp}$ specific band in the $35 \mathrm{~S}$ promoter detection and $623 \mathrm{bp}$ specific band in the cp4-epsps gene detection. In order to get more putative resistant transgenic plants, $0.3 \%$ herbicide, which was not a complete lethal concentration for sugarcane, was used in this study, although it led to higher false-positive rate. Figure 5 showed part of PCR products identified by gel electrophoresis.

3.6. Disease Incidence of Artificially Inoculated Transgenic Lines. After artificial inoculation with SrMV, 14 transgenic plants showed no symptoms and no virus in RT-PCR detection and were judged to be uninfected after SrMV challenge; two transgenic plants and nontransgenic control plants showed symptoms and SrMV in RT-PCR detection, diagnosed as infected after SrMV challenge (Figures 6 and 7). Therefore, it could be concluded that hairpin RNAi expression vector pGII00-HACP, which resulted in production of resistance against SrMV, was successfully introduced into sugarcane and according to $87.5 \%$ transgenic plants showed improved resistance to SrMV.

\section{Discussion}

Mosaic virus-resistant transgenic sugarcane plants have been obtained via particle gun bombardment [14, 15, 30-32], and some transgenic plants were significantly improved in mosaic virus resistance. However, most events produced by gene gun bombardment tend to show high copy numbers of recombinant inserts [33]. Modern sugarcane varieties are a complex allopolyploid and aneuploid genetic background of S. officinarum (chromosome number 80) and S. spontaneum (chromosome number from 40 to 128), with even Erianthus arundinaceus included in sugarcane clones bred during last five years in China [34]. Hence, it was hard to prove clearly characters such as copy numbers, insertion sites, and border sequences in genetically modified (GM) sugarcane via gun bombardment. However, such information is necessary for any GM organisms including GM sugarcane before the application of transgenic field trials. Also high copy numbers of exogenous genes, such as the selective marker, in GM organism can even cause cosuppression [35].

It has been reported that Agrobacterium-mediated transformation leads to clean, discrete, low copy, well-defined, unrearranged DNA insertions into the plant genome [36, 37]. However, Agrobacterium-mediated transformation is not as successful as gene gun bombardment in sugarcane. In the present study, hairpin RNAi expression vector pGII00HACP was transferred to sugarcane cultivar ROC22 via Agrobacterium-mediated method. The $423 \mathrm{bp}$ interference 


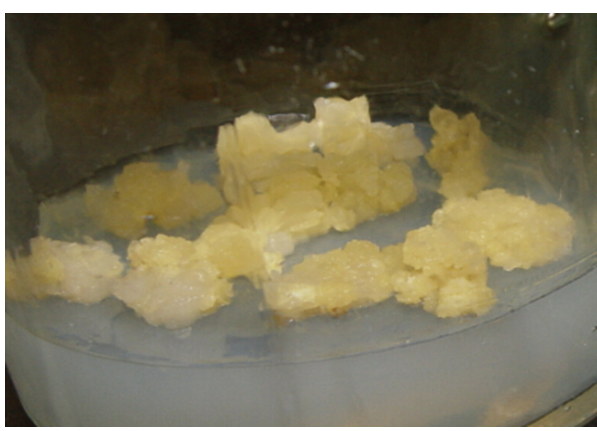

(a)

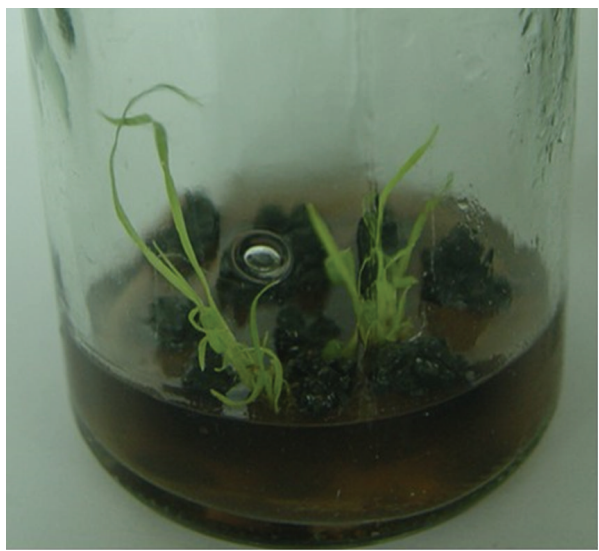

(c)

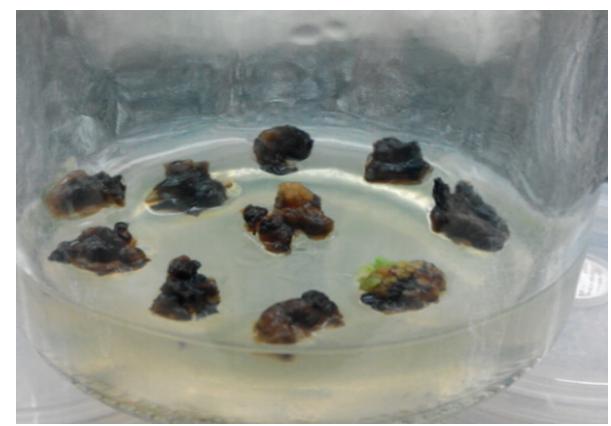

(b)

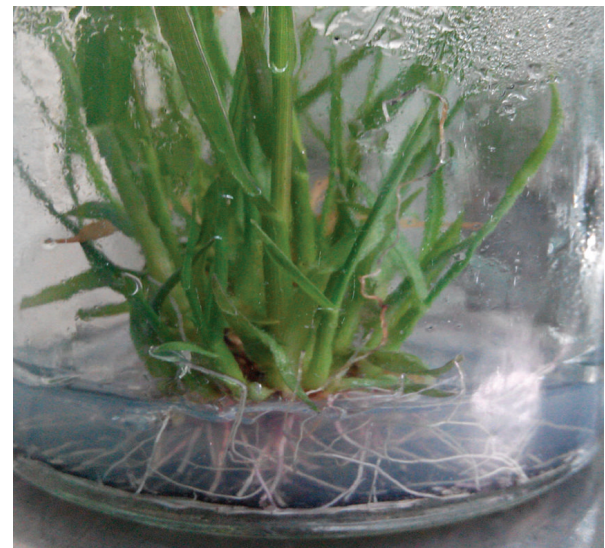

(d)

FIGURE 3: Putative recombinant screening. (a) Wild-type calli, (b) transformed calli screening by herbicide, (c) regenerated seedlings at the stage of differentiation selection culture, and (d) regenerated seedlings at the stage of rooting culture.

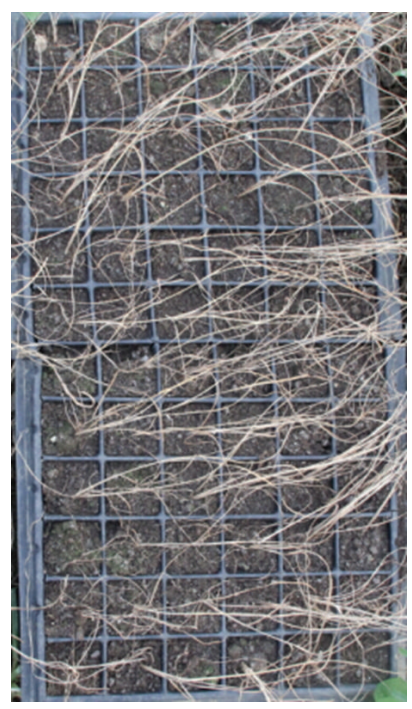

(a)

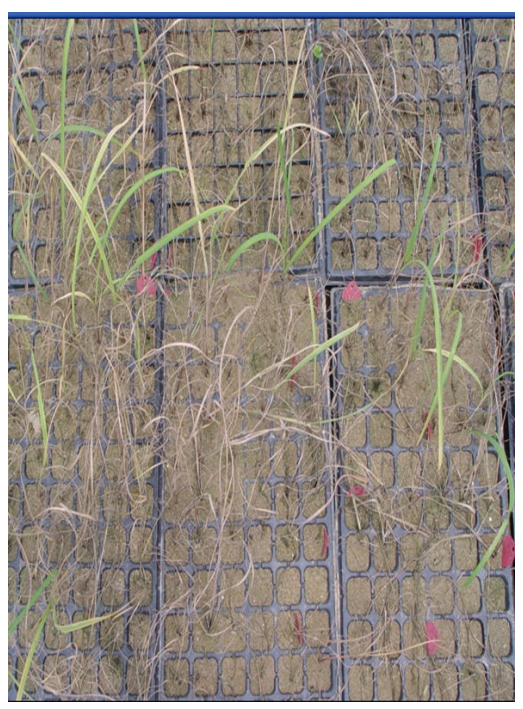

(b)

FIGURE 4: Spraying screening by $0.3 \%$ herbicide. (a) Wild-type plants and (b) putative transformants.

fragment derived from the most conservative region of the CP gene of SrMV based on multiple alignment analysis of all the three SrMV strains (H, I, and M). The purpose is to obtain multistrains resistant sugarcane plants. In addition, cp4-epsps gene contained in pGII00-HACP can be used as a high-efficiency selective marker and also endows sugarcane with a herbicide-tolerant trait. This enables farmers to make the process of weed control more efficient and flexible.

RNAi is a highly conserved dsRNA-guided mechanism that mediates sequence-specific posttranscriptional gene 


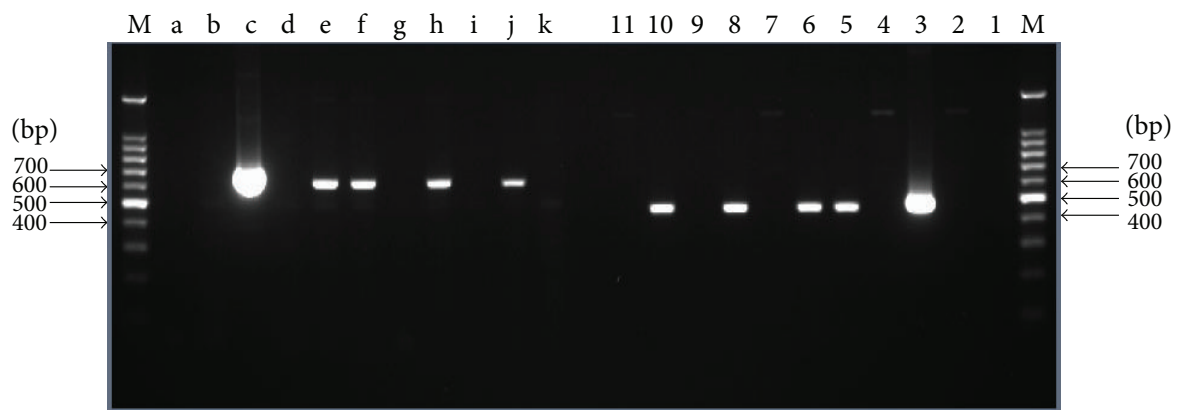

FIGURE 5: PCR amplification products of cp4-epsps gene and 35S promoter. M: DNA marker; d k: 35S promoter detection; 4 11: cp4-epsps gene detection; $\mathrm{c}$ and 3: positive control; $\mathrm{b}$ and 2: negative control; a and 1: $\mathrm{ddH}_{2} \mathrm{O}$ blank control.

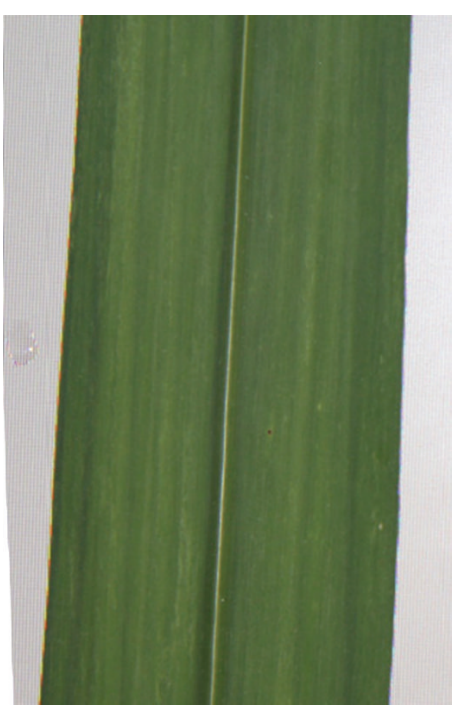

(a)

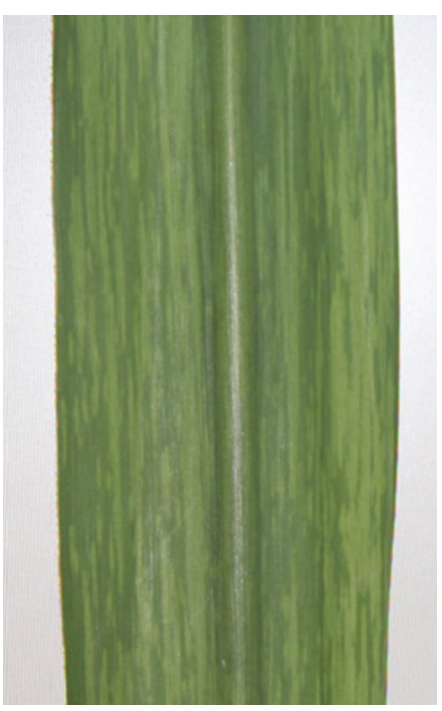

(b)

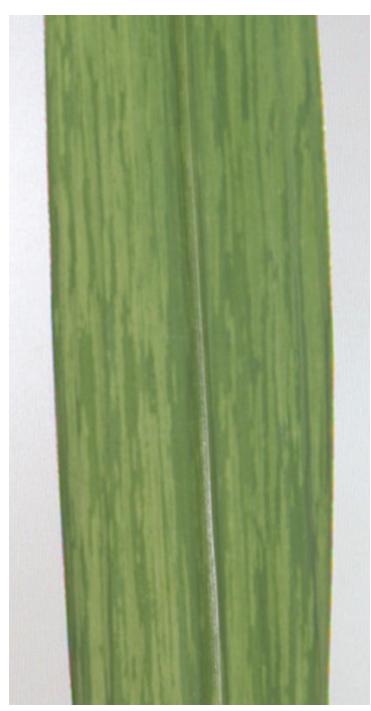

(c)

Figure 6: The SrMV-resistant and sensitive symptoms. (a) Transgenic plants had no symptoms; (b) transgenic plants displayed symptoms; (c) nontransgenic control plants displayed appeared symptoms.

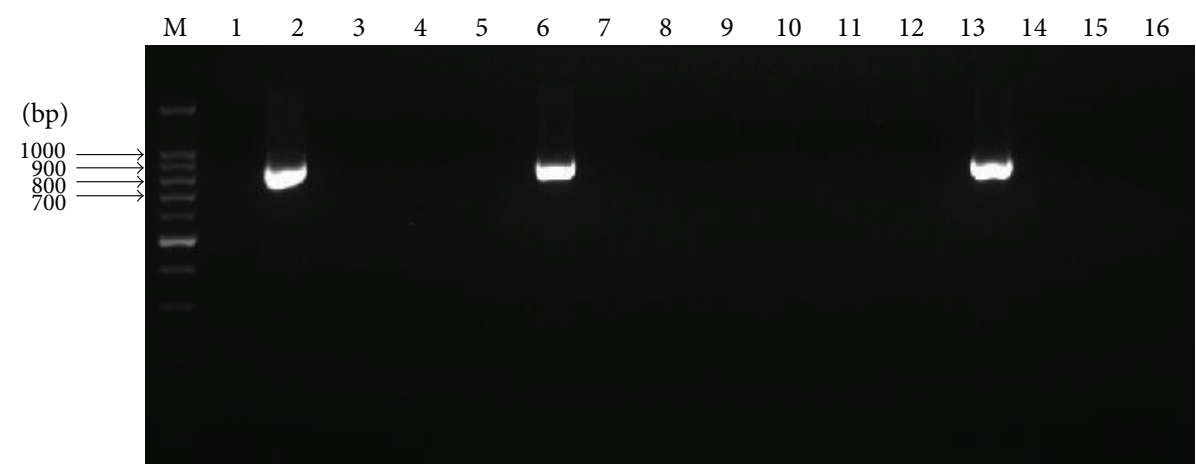

FIGURE 7: RT-PCR detection of SrMV in experimental plants. M: DNA marker; 1: $\mathrm{dd}_{2} \mathrm{O}$ blank control; 2: nontransgenic control showed symptoms; 3 6, 8 14, and 16: transgenic plants without symptoms; 7, 15: transgenic plants showed symptoms.

silencing [38]. As a source of dsRNA, plasmid-expressed short hairpin RNA (shRNA) has been demonstrated to be able to trigger RNAi silencing [21-24]. The study of Varsha Wesley et al. [39] showed that intron-containing constructs (ihpRNA) can generally enable $90-100 \%$ of independent transgenic plants to show silencing. The average percentages of ihpRNA, hpRNA, cosuppression, and antisense constructs at silencing were $90 \%, 58 \%, 13 \%$, and $12 \%$, respectively [39]. pHANNIBAL, an intermediate generic vector used in this study, allows a simple, single PCR product from CP gene to 
be easily converted into a highly effective ihpRNA silencing construct. Similar to Varsha Wesley et al. [39], the ihpRNA silencing construct targeting SrMV CP gene in this study exhibited $87.5 \%$ high silencing effect.

In summary, a $423 \mathrm{bp}$ highly conserved region from the $\mathrm{CP}$ gene of SrMV was selected as the interference sequence based on multiple alignment analysis of all the three SrMV strains ( $\mathrm{H}, \mathrm{I}$, and $\mathrm{M}$ ) and several other isolates. The hairpin RNAi expression vector pGII00-HACP was transferred to sugarcane cultivar ROC22 via Agrobacterium-mediated transformation. After herbicide screening, PCR molecular identification, and artificial inoculation challenge, anti-SrMV positive transgenic lines were successfully obtained. This study provides the foundation for a further study on silencing mechanism of SrMV-CP gene expression based on RNA interference and provides novel materials to evaluate the silencing effect connected with exogenous gene copy numbers and insertion sites. It also provides new material for broad-spectrum antiviral sugarcane breeding.

\section{Conflict of Interests}

The authors declare that there is no conflict of interests regarding the publication of this paper.

\section{Authors' Contribution}

Jinlong Guo and Shiwu Gao equally contributed to this paper.

\section{Acknowledgments}

This work was supported by the National Natural Science Foundation of China (30871581), the Earmarked Fund for the Modern Agroindustry Technology Research System (CARS20 ), and the 948 Program on the Introduction of International Advanced Agricultural Science and Techniques of the Department of Agriculture (2014-S18).

\section{References}

[1] J. L. Guo, L. P. Xu, Y. C. Su et al., "ScMT2-1-3, a metallothionein gene of sugarcane, plays an important role in the regulation of heavy metal tolerance/accumulation," BioMed Research International, vol. 2013, Article ID 904769, 12 pages, 2013.

[2] R. K. Chen, L. P. Xu, Y. Q. Lin et al., Chinese Monograph: Modern Sugarcane Genetic Breeding, China Agriculture Press, 2011.

[3] Y. Xie, M. Wang, D. Xu, R. Li, and G. Zhou, "Simultaneous detection and identification of four sugarcane viruses by onestep RT-PCR," Journal of Virological Methods, vol. 162, no. 1-2, pp. 64-68, 2009.

[4] F. Revers, O. L. Gall, T. Candresse, and A. J. Maule, "New advances in understanding the molecular biology of plant/potyvirus interactions," Molecular Plant-Microbe Interactions, vol. 12, no. 5, pp. 367-376, 1999.

[5] Z. N. Yang and T. E. Mirkov, "Sequence and relationships of sugarcane mosaic and sorghum mosaic virus strains and development of RT-PCR-based RFLPS for strain discrimination," Phytopathology, vol. 87, no. 9, pp. 932-939, 1997.
[6] V. R. Mali and R. P. Thakur, "Natural infection of sugarcane by an immunity breaking strain of sorghum mosaic potyvirus (SR MV-IBS) in peninsular India," Sugar Tech, vol. 2, no. 3, pp. 2025, 2000.

[7] C. G. Marcos, P. R. Luciana, C. S. Silvana, and G. A. L. Marcros, "Virus diseases of sugarcane A constant challenge to sugarcane breeding in Brazil," Functional Plant Science and Biotechnology, vol. 6, pp. 108-112, 2012.

[8] M. P. Grisham and Y.-B. Pan, "A genetic shift in the virus strains that cause mosaic in Louisiana sugarcane," Plant Disease, vol. 91, no. 4, pp. 453-458, 2007.

[9] Y. H. Chen, Z. J. Zhou, Q. Y. Lin, and L. H. Xie, "A preliminary report on strains of sugarcane mosaic virus," Chinese Journal: Journal of Fujian Agriculture College, vol. 17, no. 1, pp. 44-48, 1988.

[10] Y. Guo, "Identification of the viral pathogen of sugarcane mosaic disease in 4 sugarcane planting states of China and gene analysis of virus protein," in Chinese Degree: Fujian Agriculture and Forestry University, Supervisor: M. Q. Zhang, pp. 26-27, 2008.

[11] P. P. Abel, R. S. Nelson, B. de et al., "Delay of disease development in transgenic plants that express the tobacco mosaic virus coat protein gene," Science, vol. 232, no. 4751, pp. 738-743, 1986.

[12] E. Gammelgård, M. Mohan, and J. P. T. Valkonen, "Potyvirusinduced gene silencing: the dynamic process of systemic silencing and silencing suppression," Journal of General Virology, vol. 88, no. 8, pp. 2337-2346, 2007.

[13] P. A. Joyce, R. B. McQualter, J. A. Handley, J. L. Dale, R. M. Harding, and G. R. Smith, "Transgenic sugarcane resistant to sugarcane mosaic virus," in Proceedings of the 20th Conference of the Australian Society of Sugar Cane Technologists, Ballina, Australia, 1998.

[14] I. L. Ingelbrecht, J. E. Irvine, and T. E. Mirkov, "Posttranscriptional gene silencing in transgenic sugarcane. Dissection of homology-dependent virus resistance in a monocot that has a complex polyploid genome," Plant Physiology, vol. 119, no. 4, pp. 1187-1198, 1999.

[15] W. Yao, A. L. Yu, J. S. Xu, G. L. Geng, M. Q. Zhang, and R. K. Chen, "Analysis and identification for transgenic sugarcane of ScMV-CP gene," Chinese Journal of Molecular Plant Breeding, vol. 2, no. 1, pp. 13-18, 2004.

[16] A. Aigner, "Gene silencing through RNA interference (RNAi) in vivo: strategies based on the direct application of siRNAs," Journal of Biotechnology, vol. 124, no. 1, pp. 12-25, 2006.

[17] H. J. Kim, M.-J. Kim, J. H. Pak et al., "Characterization of SMV resistance of soybean produced by genetic transformation of SMV-CP gene in RNAi," Plant Biotechnology Reports, vol. 7, no. 4, pp. 425-433, 2013.

[18] Y. B. Niu, D. F. Wang, M. Yao, Z. Yan, and W. X. You, "Transgenic tobacco plants resistant to two viruses via RNA silencing," Acta Agronomica Sinica, vol. 37, no. 3, pp. 484-488, 2011.

[19] E. Bucher, D. Lohuis, P. M. J. A. van Poppel, C. GeertsDimitriadou, R. Goldbach, and M. Prins, "Multiple virus resistance at a high frequency using a single transgene construct," Journal of General Virology, vol. 87, no. 12, pp. 3697-3701, 2006.

[20] V. O. Ntui, K. Kynet, P. Azadi et al., "Transgenic accumulation of a defective cucumber mosaic virus (CMV) replicase derived double stranded RNA modulates plant defence against CMV strains $\mathrm{O}$ and $\mathrm{Y}$ in potato," Transgenic Research, vol. 22, no. 6, pp. 1191-1205, 2013.

[21] M.-B. Wang, D. C. Abbott, and P. M. Waterhouse, "A single copy of a virus-derived transgene encoding hairpin RNA 
gives immunity to barley yellow dwarf virus," Molecular Plant Pathology, vol. 1, no. 6, pp. 347-356, 2000.

[22] C.-Y. Lin, H.-M. Ku, W.-S. Tsai, S. K. Green, and F.-J. Jan, "Resistance to a DNA and a RNA virus in transgenic plants by using a single chimeric transgene construct," Transgenic Research, vol. 20, no. 2, pp. 261-270, 2011.

[23] Z.-Y. Zhang, L. Yang, S.-F. Zhou, H.-G. Wang, W.-C. Li, and F.-L. Fu, "Improvement of resistance to maize dwarf mosaic virus mediated by transgenic RNA interference," Journal of Biotechnology, vol. 153, no. 3-4, pp. 181-187, 2011.

[24] T. Shimizu, E. Nakazono-Nagaoka, F. Akita et al., "Hairpin RNA derived from the gene for Pns9, a viroplasm matrix protein of Rice gall dwarf virus, confers strong resistance to virus infection in transgenic rice plants," Journal of Biotechnology, vol. 157, no. 3, pp. 421-427, 2012.

[25] K. Osabe, S. R. Mudge, M. W. Graham, and R. G. Birch, "RNAi mediated down-regulation of PDS gene expression in sugarcane (Saccharum), a highly polyploid crop," Tropical Plant Biology, vol. 2, no. 3, pp. 143-148, 2009.

[26] J. H. Jung, W. M. Fouad, W. Vermerris, M. Gallo, and F. Altpeter, "RNAi suppression of lignin biosynthesis in sugarcane reduces recalcitrance for biofuel production from lignocellulosic biomass," Plant Biotechnology Journal, vol. 10, no. 9, pp. 1067-1076, 2012.

[27] M. Holsters, D. de Waele, A. Depicker, E. Messens, M. van Montagu, and J. Schell, "Transfection and transformation of Agrobacterium tumefaciens," Molecular \& General Genetics, vol. 163, no. 2, pp. 181-187, 1978.

[28] M. Gómez, A. M. Rago, and G. Serino, "Rapid identification of viruses causing sugarcane mosaic by direct sequencing of RTPCR products from crude extracts: a method for large scale virus surveys," Journal of Virological Methods, vol. 157, no. 2, pp. 188-194, 2009.

[29] A. Użarowska, G. Dionisio, B. Sarholz et al., "Validation of candidate genes putatively associated with resistance to SCMV and MDMV in maize (Zea mays L.) by expression profiling," BMC Plant Biology, vol. 9, article 15, 2009.

[30] G. R. Smith, R. L. Gambley, and B. T. Egan, "Progress in development of a sugarcane meristem transformation system and production of SCMV-resistant transgenics," Proceedings of the Australian Society of Sugar Cane Technologists, vol. 15, pp. 237-250, 1994.

[31] R. A. Gilbert, M. Gallo-Meagher, J. C. Comstock, J. D. Miller, M. Jain, and A. Abouzid, "Agronomic evaluation of sugarcane lines transformed for resistance to Sugarcane mosaic virus strain E," Crop Science, vol. 45, no. 5, pp. 2060-2067, 2005.

[32] Y. Guo, M. H. Ruan, W. Yao, L. Chen, R. K. Chen, and M. Q. Zhang, "Difference of coat protein mediated resistance to sugarcane mosaic virus between Badila and Funong 91-4621," Journal of Fujian Agriculture and Forestry University (Natural Science Edition), vol. 37, no. 1, pp. 7-12, 2008 (Chinese).

[33] A. D. Arencibia, E. R. Carmona, P. Téllez et al., "An efficient protocol for sugarcane (Saccharum spp. L.) transformation mediated by Agrobacterium tumefaciens," Transgenic Research, vol. 7, no. 3, pp. 213-222, 1998.

[34] B. Xue, J. Guo, Y. Que, Z. Fu, L. Wu, and L. Xu, "Selection of suitable endogenous reference genes for relative copy number detection in sugarcane," International Journal of Molecular Sciences, vol. 15, no. 5, pp. 8846-8862, 2014.

[35] W. Tang, R. J. Newton, and D. A. Weidner, "Genetic transformation and gene silencing mediated by multiple copies of a transgene in eastern white pine," Journal of Experimental Botany, vol. 58, no. 3, pp. 545-554, 2007.

[36] A. R. Wenck, M. Quinn, R. W. Whetten, G. Pullman, and R. Sederoff, "High-efficiency agrobacterium-mediated transformation of Norway spruce (Picea abies) and loblolly pine (Pinus taeda)," Plant Molecular Biology, vol. 39, no. 3, pp. 407-416, 1999.

[37] M. N. Somleva, Z. Tomaszewski, and B. V. Conger, "Agrobacterium-mediated genetic transformation of switchgrass," Crop Science, vol. 42, no. 6, pp. 2080-2087, 2002.

[38] G. Meister and T. Tuschl, "Mechanisms of gene silencing by double-stranded RNA," Nature, vol. 431, no. 7006, pp. 343-349, 2004.

[39] S. Varsha Wesley, C. A. Helliwell, N. A. Smith et al., "Construct design for efficient, effective and high-throughput gene silencing in plants," Plant Journal, vol. 27, no. 6, pp. 581-590, 2001. 

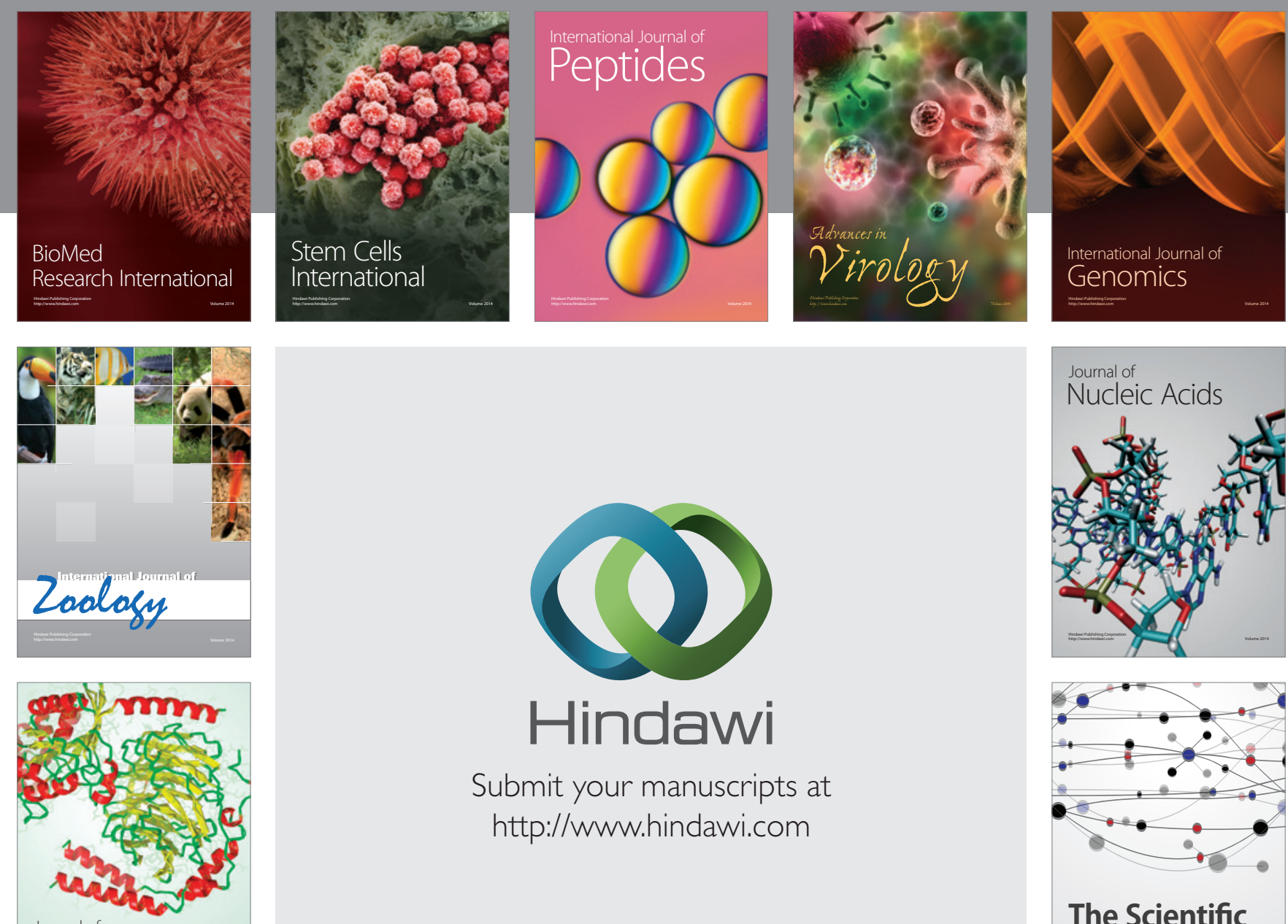

Submit your manuscripts at

http://www.hindawi.com

Journal of
Signal Transduction
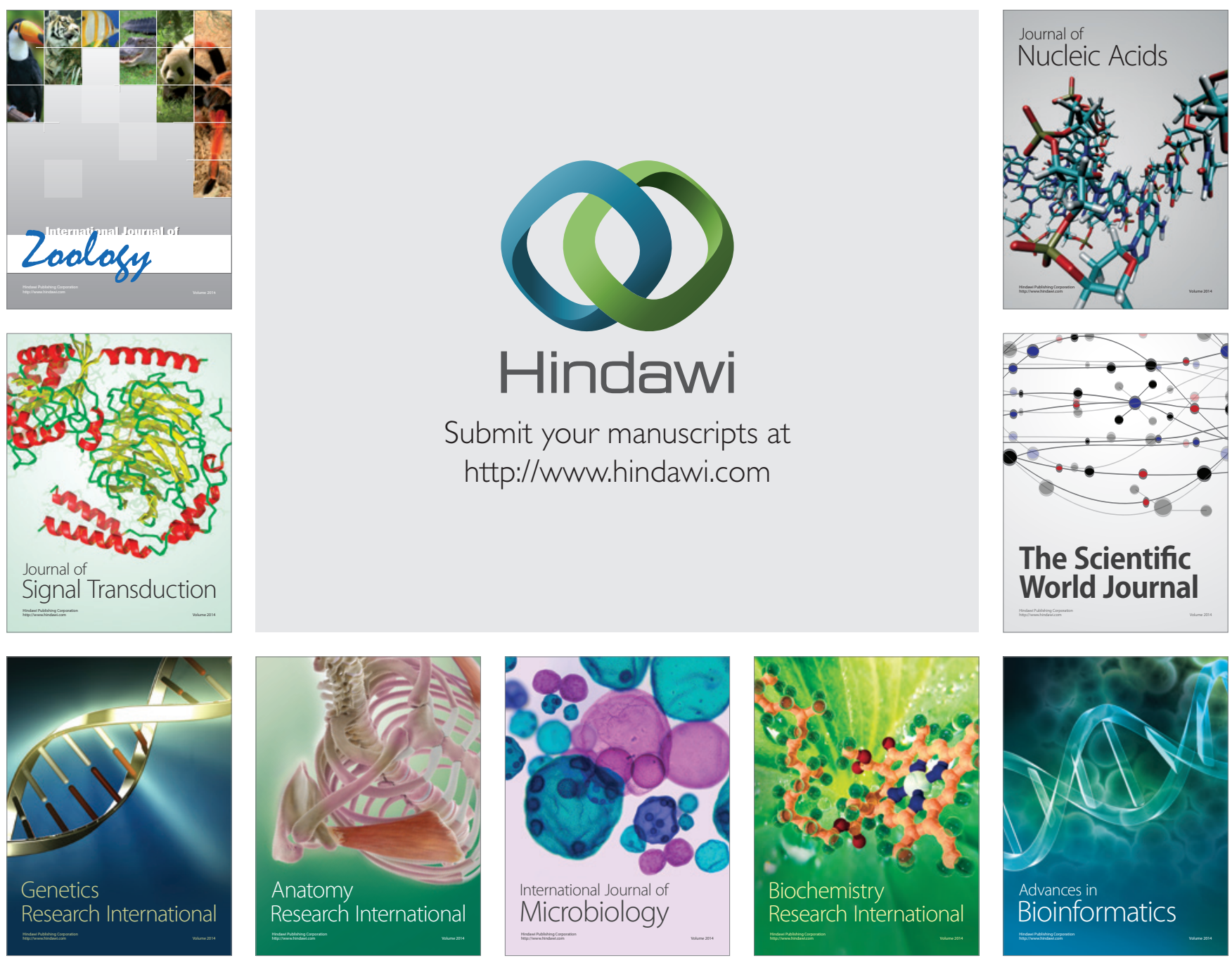

The Scientific World Journal
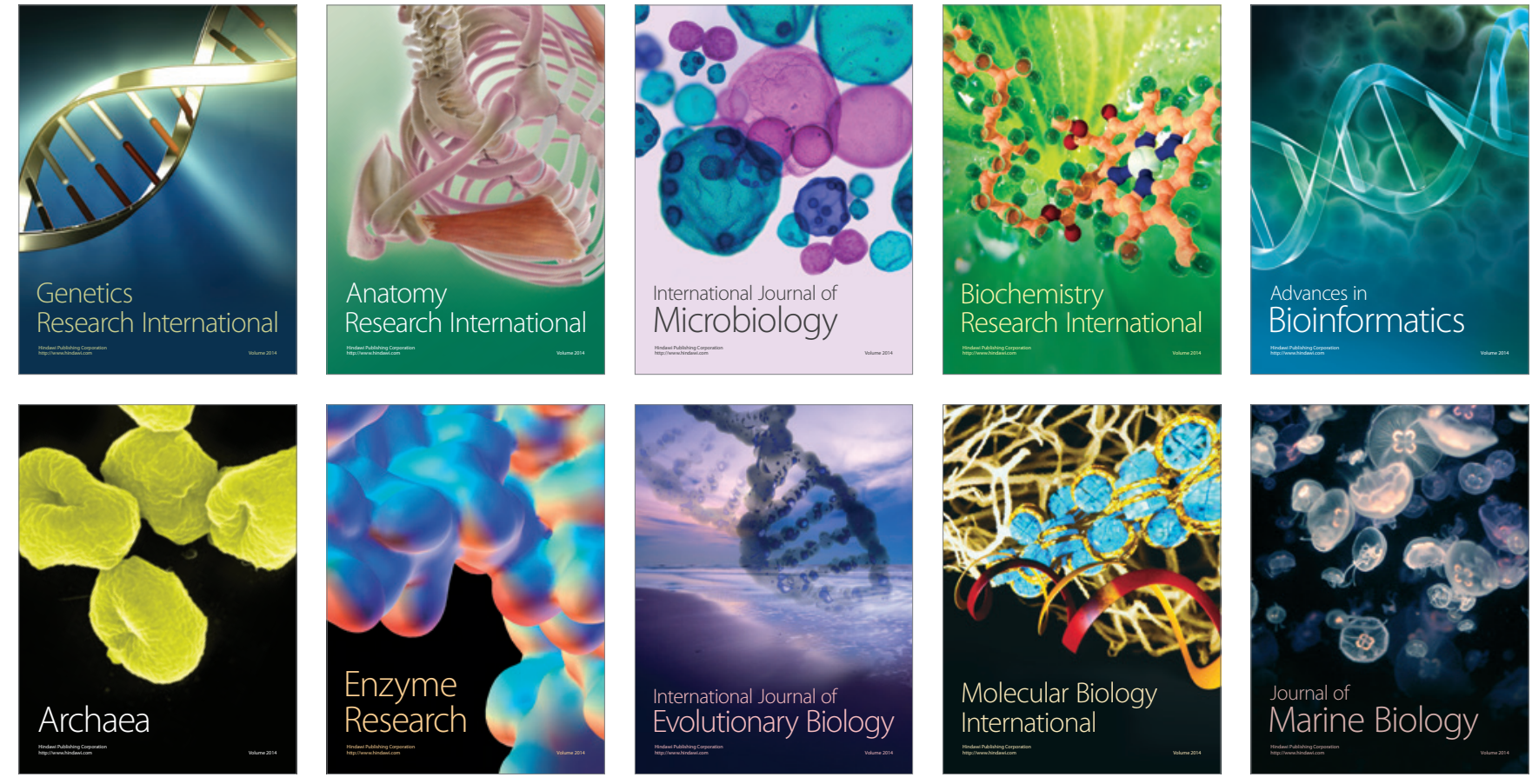